\title{
REPRESENTAÇÃO POLÍTICA: UM DIÁLOGO ENTRE A PRÁTICA E A TEORIA
}

\author{
Daniela Resende Archanjo
}

\begin{abstract}
RESUMO
O presente ensaio discute a questão da representação politica a partir do diálogo entre a teoria e a prática políticas. Partindo da caracterização das três formas de representação apontadas pela bibliografia (representação como delegação, como confiança e como representatividade sociológica) o texto busca revelar, a partir das falas de deputados e senadores que participaram do debate acerca da instituição do divórcio no Brasil durante as décadas de 1950, 1960 e 1970, como as diferentes possibilidades do conceito de representação política foram entendidas e mobilizadas no debate político no Congresso Nacional. O espaço em que se inscrevem a Câmara dos Deputados e o Senado Federal, cenário da política por excelência, é multifacetário, enquanto a prática parlamentar constitui-se na mistura (não consciente) dos modelos teóricos, sendo que sempre prevalece a necessidade de expressar a importância da manutenção do vínculo com o eleitor. É preciso não perder de vista que os discursos dos políticos são, antes de tudo, produtos do contexto em que estão inscritos, forjadas pelo significado atribuído pelos parlamentares à sua função de representantes políticos.
\end{abstract}

PALAVRAS-CHAVE: representação politica; teoria política; prática política; divórcio.

\section{INTRODUÇÃO}

O presente ensaio tem como objetivo fazer uma breve discussão teórica sobre as possibilidades do conceito de "representação política" para analisar como os parlamentares brasileiros entenderam e mobilizaram essas possibilidades durante o debate sobre a instituição do divórcio no Brasil nas décadas de 1950, 1960 e 1970. O estudo utilizou como fonte de pesquisa os Anais da Câmara dos deputados, do Senado Federal e do Congresso Nacional, mais especificamente, os registros dos discursos parlamentares proferidos sobre casamento, família, separação e divórcio no Brasil entre 1951 e 19771 .

As dificuldades próprias ao processo legislativo, assim como as diferenças ideológicas

\footnotetext{
1 Este trabalho é parte de um estudo feito sobre as discussões acerca da instituição do divórcio na legislação pátria travadas no Congresso Nacional Brasileiro entre os anos de 1951 e 1977. A decisão por estabelecer o início do recorte temporal em 1951 deveu-se ao fato de ter sido este o ano de início das atividades parlamentares do grande nome na luta a favor do divórcio, o então Deputado Federal Nelson Carneiro. Foi também em 1951 que este apresentou o primeiro de seus muitos projetos com cunho divorcista, o Projeto de
}

pessoais ou partidárias, remetiam os parlamentares a pensarem (e mesmo justificarem) sua função como representantes, expressando em determinados momentos de seus discursos o que entendiam por representação e a quem entendiam ou pretendiam representar.

A clareza sobre o poder que o parlamentar detinha em relação à feitura e interpretação das leis foi expressa pelo Deputado Campos Vergal, quando, em 1962, afirmou: "Quem faz as leis somos nós. Tanto quanto eu, V. Exa. [Arruda Câmara] é Constituinte de 1946. Lutamos, nesta casa - lá no Rio, bem entendido -, em várias questões, discordando muitas vezes na elaboração da Constituição de 1946. Logo, não venha dizer que são

Lei n. 786/1951, que propunha a possibilidade de anulação de casamento por incompatibilidade invencível entre os cônjuges. O marco final da análise não poderia ter sido outro, já que foi em 1977 que a Emenda Constitucional n. 9/1977 foi aprovada, retirando a indissolubilidade do texto da Constituição Federal e, conseqüentemente, permitindo a aprovação, no mesmo ano, do Projeto de Lei n. 156/1977 apresentado pelos senadores Nelson Carneiro e Accioly Filho, que resultou na Lei n. 6.515/1977, a Lei do Divórcio. Sobre o trabalho, ver Archanjo (2008). 
princípios vindos de milênios diretamente de um deus desconhecido; que é lei natural e impositiva. Não, Srs., a Constituição, nós a fizemos; as leis, nós as fizemos e devemos interpretá-las de acordo com nosso pensamento e com a realidade da hora que passa" (VERGAL, 1962, p. 1595).

Note-se que, ao mesmo tempo em que o Deputado ressaltava a autonomia do parlamentar que, de certo modo, monopolizava o poder de legislar e ainda o de interpretar as leis, Campos Vergal também chamava a atenção para a responsabilidade inerente a essa função. Como as leis não são "naturais e impositivas", mas sim fruto de construção social (produto do trabalho dos parlamentares e também de outros setores da sociedade), aqueles que ocupavam o lugar na ponta desse sistema, ou seja, aqueles que efetivamente participavam do processo de feitura da lei, discutindo e votando, deveriam assumir também o ônus colocado como inerente à representação.

Tomando como ponto de partida os estudos teóricos desenvolvidos no campo da Ciência Política, passaremos a discutir, a partir das falas dos parlamentares brasileiros que discursaram sobre o divórcio de 1951 a 1977, como deputados e senadores entenderam e mobilizaram as diferentes possibilidades do conceito de representação política. Segundo Cotta (1992, p. 1102), estudiosos da Ciência Política apontam três modelos interpretativos alternativos sobre o conteúdo da função representativa e o papel dos representantes políticos: 1) a representação como relação de delegação; 2) como relação de confiança; 3) como "espelho" ou representatividade sociológica. Em linhas gerais, na primeira o representante recebe um mandato imperativo, que o vincula a exercer ou manifestar de modo exato a vontade do representado. A segunda pressupõe a autonomia do mandatário, que recebe do representado uma espécie de mandato fiduciário ${ }^{2}$, sem caráter vinculante. Por fim, a representação como "espelho" tem o significado de representatividade, isto é, de semelhança ou de proporcionalidade da parte (representante) com o todo (representados).

Em seu clássico estudo sobre o conceito de representação, Hanna Pitkin trata do desenvolvimento etimológico do conceito moderno de representação, assim como do seu desenvolvimen-

\footnotetext{
2 Derivado de fidúcia, que significa confiança.
}

to na teoria política, estudando as práticas históricas de representação política. De acordo com a autora, no latim clássico a palavra representare, que significa "tornar presente ou manifesto; ou apresentar novamente", tem seu uso quase inteiramente reservado para objetos inanimados. "Até o século XVI não se encontra um exemplo de 'representar' com o significado de 'tomar ou ocupar o lugar de outra pessoa, substituir'; e até 1595 não há um exemplo de representar como 'atuar para alguém como seu agente autorizado ou Deputado"” (PITKIN, 2006, p. 20). Esse conceito moderno de representação, que contempla aspectos politicamente significativos, foi finalizado antes do final do século XVII, tendo o Leviathan de Thomas Hobbes como obra fundamental, em que a representação é definida em termos de autorização. A professora da Universidade de Berkeley aponta que "ao chamar o soberano de representante, Hobbes constantemente sugere que o soberano fará o que se espera que os representantes façam, não apenas o que lhe satisfaz. No entanto, a definição formal assegura que essa expectativa nunca pode ser invocada para criticar o soberano ou resistir a ele por não representar seus súditos como deveria" (idem, p. 29).

De acordo com Mezzaroba, na cultura ocidental o sentido atribuído à representação é "o de tornar presente algo que, na verdade, encontra-se mediatizado" (MEZZAROBA, 2004, p. 10). Entendida como fazer presente alguém que está ausente, a representação exclui a presença, ou seja, a priori, o representante nunca falaria em seu próprio nome, como defensor de interesses pessoais. Tal entendimento foi expresso por alguns parlamentares, estando estampado em declarações do tipo: "o Deputado não [...] [vai] ao Congresso para defender as suas idéias particulares" (FARACO, 1952 , p. 1365). O porte da procuração outorgada pelas urnas eleitorais, com fins de representação política, serve para legitimar a ação parlamentar ao mesmo tempo em que a onera com o dever de responsabilidade. Ou seja, ao mesmo tempo em que o parlamentar recebe o poder de manifestar-se de maneira direta, tendo direito a voz e voto, sem intermediários físicos, o desempenho desta função fica adstrita aos limites inerentes à representação, em especial, a responsabilidade de fazer presente quem está ausente (quem não pode participar diretamente das discussões e votações - os eleitores). Nesse sentido, o Deputado Cid Furtado afirmou: "O poder de representar é algo que transcende a vontade pessoal do mandatário. Ao revés, não serí- 
amos dignos da procuração passada no cartório cívico das urnas" (FURTADO, 1975, p. 1102).

Citando texto atribuído a Rui Barbosa, o Deputado Arruda Câmara chamava a atenção para esses limites da ação parlamentar. Afirmando que "o mandato dos parlamentares não deve exorbitar do que os eleitores reivindicam" (CÂMARA, 1956, p. 13), o Deputado delimitava o espaço do representante que, de acordo com este entendimento, não podia ficar aquém e nem ir além do outorgado pela representação - entendida como delegação dos eleitores.

Ao declarar que estava votando contra suas convicções pessoais, mas em consonância com a vontade de seus mandantes, o Deputado João Agripino deixou clara sua submissão à função que desempenhava, colocando-se como autêntico representante que tem por função fazer presente aquele que está ausente, independentemente de suas expectativas pessoais. João Agripino declarou: "Divorcista por convicção, voto contra a emenda constitucional número 4-A-51, que manda suprimir do artigo 163 da Constituição Federal a expressão 'de vínculo indissolúvel', porque, representando, como represento, nesta Casa, um eleitorado totalmente católico e antidivorcista, não me sinto no direito de trair a sua confiança. Contrariando a minha consciência, sinto-me ainda feliz por poder não contrariar as dos que confiaram em minha conduta parlamentar" (AGRIPINO, 1952, p. 5178).

Utilizando o mesmo argumento, mas com resultado final oposto, Nina Ribeiro pronunciou: "Não quero impor a minha crença a ninguém. Não o acho justo e democrático, mesmo informado, intimamente, por razões religiosas, a não recorrer ao divórcio. Não acho justo impô-la coativamente, com feição medievalesca, a outrem que não comungue da mesma crença, ou mesmo comungando da mesma crença, não com expediente tão extremado, pois há que se admitir a falibilidade da criatura humana, que pode desejar reerguer-se com nova oportunidade. A Igreja - aprende desde a Proclamação da República, Srs. Congressistas é separada do Estado. Portanto, não há que confundir a lei civil com a lei canônica. Sendo ambos os institutos separados, não vejo por que se querer confundi-los, ou torna-los absolutamente iguais, imposto a outros cidadãos brasileiros, que professam crenças diversas ou até que não tenham crença alguma, princípios que são inerentes, próprios, unicamente, a um grau extremado de uma determinada feição de pensar ou de agir ou de religiosidade" (RIBEIRO, 1976, p. 163).

Vale ressaltar que, tratando-se de discursos proferidos no Congresso Nacional, espaço político por excelência, a questão da necessidade de o parlamentar preservar o vínculo de confiança em relação ao seu eleitor, a fim de garantir uma futura reeleição, é uma constante. Assim, ao mesmo tempo em que os deputados João Agripino e Nina Ribeiro vitimizavam-se, por abrirem mão de sua autonomia em favor de seus eleitores, fortaleciam o vínculo representante-representados, robustecendo seus mandatos.

A tendência dos parlamentares de colocaremse como delegados de seus representantes, dizendo-se cumpridores de ordens, pode ser apontada como uma estratégia de autopreservação, na medida em que sugere uma transferência de responsabilidade ou, pelo menos, remete à corresponsabilidade. A conhecida necessidade do parlamentar de manter o vínculo com o eleitor para garantir a recondução ao cargo aponta também para a hipótese de que suas palavras estão sempre, em certo sentido, viciadas. O vício está no que chamaremos de "limites do dizer", ou seja, restrições mais ou menos explícitas à forma como o parlamentar expressa-se e a seu posicionamento frente às questões. O Congresso Nacional é um espaço de disputa de poder, ou melhor, de poderes, que evidentemente não se limitam ao debate sobre o divórcio.

\section{A REPRESENTAÇÃO COMO DELEGAÇÃO}

Entendida como "substituir, agir no lugar de ou em nome de alguém ou de alguma coisa; evocar simbolicamente alguém ou alguma coisa; personificar" (COTTA, 1992, p. 1102), a representação remete à dinâmica teatral, na qual o ator interpreta o personagem, reproduzindo suas práticas e comportamentos e incorporando seus pensamentos e sentimentos. Essa função de representação, em que alguém é delegado a cumprir uma tarefa específica, circunscrito aos limites estabelecidos pelo mandante, exercendo o papel de um simples executor da vontade alheia, sem qualquer autonomia, corresponde também à representação exercida no âmbito do direito civil. Essa é a natureza do mandato outorgado, por exemplo, a um procurador que deve servir como porta-voz de seu representado, expressando os desejos e promovendo a defesa dos interesses daquele a quem representa. 
Mas, ao contrário de como o mandato configura-se no direito civil, no direito público, em que o contingente de representados é bem maior e, na maior parte das vezes, heterogêneo, torna-se difícil exercer a representação política dessa forma tão direta (MIGUEL, 2005, p. 26). Assim, a representação como relação de delegação não diz respeito à representação direta e individualizada, mas corresponde à representação de um determinado grupo da sociedade, que pode estar relacionado à ideologia política, à opção religiosa, à posição econômica, à posição geográfica, à categoria profissional ou a qualquer outro grupo com interesse singular.

\section{II.1. Partidos políticos}

Pensando em grupos com interesses singulares, a filiação partidária talvez pudesse ser apontada como a forma mais autêntica de delegação, já que os partidos políticos estabeleciam em seus estatutos regras a serem seguidas e defendidas por seus membros. A "fidelidade partidária, levando mesmo à idéia da perda do mandato do Deputado que tenha rompido com a disciplina devida à agremiação pela qual foi eleito" (SOUZA, 1971, p. 59), remete ao mandato imperativo, na medida em que "a amplitude do mandato representativo e a liberdade dos representantes sofrem restrições" (idem, p. 58) devendo subordinar-se ao programa do respectivo partido.

Todavia, "embora seja certo que somente o Estado Novo varguista (1937-1945) prescindiu por completo da intermediação partidária, o que se constata é que o poder central brasileiro sempre conviveu com partidos frouxamente organizados, e, mais do que isto, parece ter sempre dificultado ou procurado impedir deliberadamente o fortalecimento dessa instituição" (LAMOUNIER \& MENEGUELLO, 1986, p. 11). Assim, as peculiaridades do sistema partidário brasileiro afastam a possibilidade de estabelecer-se uma relação causal entre filiação partidária e posição ante o divórcio.

Durante o período multipartidário (1951$1965)^{3}$, em discursos proferidos sobre casamento, família, separação e divórcio, alguns parlamentares expressaram a posição "formal" de seus par-

\footnotetext{
3 O período multipartidário teve início em 1945 e perdurou até 1965 , todavia, em função do recorte temporal deste trabalho, iremos referir-nos apenas aos discursos proferidos a partir de 1951
}

tidos em relação à questão do divórcio. De acordo com os deputados e senadores, o Partido Social Progressista (PSP), o Partido Social Democrata (PSD) e o Partido Democrata Cristão (PDC) estabeleceram diretrizes formais contra o divórcio em seus respectivos estatutos e programas, enquanto o Partido Nacionalista dos Trabalhadores (PNT), o Partido Trabalhista Brasileiro (PTB) e o Partido Social Trabalhista (PST) declararam ser esta questão aberta, sem norma firmada pelo partido.

Mas a declaração do Deputado Felix Valois deixa claro quão frágil era a ligação do voto do político com sua legenda partidária. Justificando sua falta de subordinação às regras estabelecidas no Estatuto do PSP, o Deputado afirmou: "lamentavelmente, não poderei acompanhar minha agremiação nesta oportunidade o que não significa indisciplina, mas ato de consciência" (VALOIS, 1952, p. 5173).

Analisando a constituição dos partidos políticos no Brasil e a relação dos políticos com suas respectivas agremiações, cientistas políticos explicam esse compromisso com a "consciência" ao qual se referiu o Deputado Felix Valois, enfatizando que, no Brasil, "o político tem de preservar antes de tudo o seu acesso aos centros decisórios, e secundariamente a sua lealdade a qualquer identidade partidária" (LAMOUNIER \& MENEGUELLO, 1986, p. 60). Essa atitude dos políticos é justificada como fruto da própria realidade social brasileira. "Basta lembrar, sob este aspecto, que somente $20 \%$ da população viviam em cidades de 20 mil habitantes ou mais, segundo o censo de 1950, e que apenas um em cada cinco habitantes [...] era eleitor. Essa população pobre e altamente dispersa em pequenos municípios e em áreas rurais, em um território vastíssimo, convivia com as estruturas do poder privado em sua forma mais fixa e imediata, e não com as instituições propriamente políticas" (idem, p. 43).

Especialmente nos casos de representantes de regiões pouco populosas, como era o caso de Felix Valois ${ }^{4}, \mathrm{o}$ acesso aos centros decisórios precisava ser garantido pelo estabelecimento do vínculo de confiança com um número de eleitores suficiente para garantir a eleição. Além disso, o

\footnotetext{
4 Félix Valois de Araújo foi eleito Deputado Federal, em 1950, pelo Território do Rio Branco (atual estado de Roraima) com 1418 votos.
} 
enaltecimento desse vínculo, em detrimento de qualquer outro (inclusive o partidário), era também uma forma de reafirmar o laço de fidúcia, corroborando para garantir o futuro acesso ao Parlamento por meio da reeleição. A necessidade de o político priorizar o acesso aos centros decisórios sobre a fidelidade partidária é apontada por Lamounier e Meneguello também como uma conseqüência do próprio significado atribuído pela sociedade - a mídia e também os eleitores - aos partidos políticos. De acordo com os autores: "É [...] evidente que, no Brasil, a chamada questão partidária não diz respeito apenas à indisciplina individual dos membros dos partidos, nem mesmo às mazelas faccionais que afligem este ou aquele partido. Ela se refere também à descontinuidade entre os próprios sistemas partidários que se sucederam ao longo de nossa história. Desde os liberais e conservadores do Império, reconhecíveis como tais desde a primeira metade do século passado, diversas formações totalmente distintas sucederam-se umas às outras, atrofiando-se ou sendo suprimidas pela violência, praticamente sem deixar um rastro organizacional ou um fio simbólico que pudesse ser retomado na etapa seguinte.

Como se não bastasse, o antipartidarismo pode ser considerado um traço marcante da cultura política brasileira. Na consciência social e na linguagem jornalística, são hiperabundantes as referências ao 'artificialismo' e à 'falta de autenticidade' dos partidos. Embora não possamos destacar a hipótese de que esta linguagem seja uma sobrevivência ideológica do Estado Novo, sabidamente antiliberal e antipluralista, não se trata apenas disso" (idem, p. 10).

O vínculo partidário ficou ainda mais comprometido com a reforma partidária de 1965-1966, imposta pelo Ato Complementar n. 4 (novembro de 1965). Em função da extinção do pluripartidarismo pelo Ato Institucional n. 2 (outubro de 1965), "os grupos parlamentares da situação reuniram-se na Aliança Renovadora Nacional (ARENA), enquanto que a oposição ao regime (aquela que sobrevivera às cassações) fundou o Movimento Democrático Brasileiro (MDB)" (SCHMITT, 2000, p. 34).

$\mathrm{O}$ bipartidarismo forçado elevou ainda mais o grau de heterogeneidade e de dissenso intrapartidário, colocando sob um mesmo (e grande) "guarda-chuva" diferentes ideologias e práticas, que, antes concorrentes, passaram repenti- namente a ser "aliadas" e, mais do que isso, identificadas como homogêneas. Em relação ao debate sobre o divórcio, a falta de consenso tanto na Arena quanto no MDB ficaram evidentes quando ambos partidos deliberaram considerar questão aberta a votação das emendas divorcistas. No mesmo sentido, objetivando firmar o caráter apartidário do seu projeto divorcista para, quem sabe, ampliar o número de adeptos, o Senador Nelson Carneiro afirmou em 1971: "Este projeto [Projeto de Lei n. 6/1971], Sr. Presidente, não sendo político, não pode ser examinado com olhos políticos, por um ou outro partido. Dentro do meu Partido há votos contrários ao projeto, como dentro do Partido do Governo há também altas vozes favoráveis a esta proposição" (CARNEIRO, 1971, p. 559).

Outra questão relevante quando se estudam os partidos políticos no Brasil é a vastidão territorial e a diversidade que ela comporta. As diferenças regionais resultavam, no período do pluripartidarismo, em coligações partidárias as mais diversas, o que reforçava a frouxidão dos vínculos partidários. Assim, ao mesmo tempo em que, por exemplo, o Partido Republicano Progressista (PRP) era em Pernambuco coligado com o Partido da República (PR), o PDC, o PTB, o Partido Liberal (PL) e a União Democrática Nacional (UDN), formando a Coligação Democrática Pernambucana nas eleições de 1950, o mesmo PRP formava, no Espírito Santo, a Coligação Democrática, com o PSP, o PR e o Partido Revolucionário dos Trabalhadores (PRT) e, na Bahia, constituía, com PSD e PST, a Coligação Bahiana (Dados Estatísticos, 1960).

\section{II.2. O Estado, a Cidade, a Região}

As diferenças regionais, explicitadas de certa forma na configuração das coligações partidárias, eram também reforçadas pelos parlamentares em seus discursos, quando estes se colocavam como representantes dos seus respectivos estados. É interessante perceber como a população exigia essa representação regional. Nos discursos sobre o divórcio eram bastante freqüentes as reproduções, por parte dos parlamentares, de cartas, manifestos, ofícios e outros documentos enviados por eleitores (normalmente grupo de eleitores ligados a algum tipo de organização: associação de moradores, grupos religiosos, entidades femininas etc.) sendo constante a identificação regional e a cobrança para que o parlamentar representasse aquela 
região (estado ou cidade).

Nesses registros, interesses de grupos e identidade territorial confundiam-se, fazendo parecer que existia uma homogeneidade regional-local. É como se todas as pessoas de uma determinada região compartilhassem dos mesmos interesses e desejassem uma mesma atitude de seu representante político. Nesse sentido, o Deputado Benedito Vaz leu um manifesto popular que dizia: "Espera a Família Ipamerina que os muito dignos senadores e deputados goianos estejam realmente dignos e merecedores da confiança neles depositada" (VAZ, 1962, p. 279). Braga Ramos, Deputado paranaense, também reproduziu um manifesto enviado por presidentes de entidades femininas do Paraná, em que se lia o seguinte trecho: "Apelam a Vossas Excelências para que, como representantes do Paraná, oponham-se de forma irredutível à aprovação da alteração constitucional, capaz de permitir desagregação da Família" (RAMOS, 1975, p. 365).

Vale destacar que a referência a todo o conjunto de pessoas (eleitores) de uma determinada região, em se tratando de política, tinha caráter altamente coercitivo. Se os parlamentares eram eleitos regionalmente, então a confiança dos eleitores deveria ser preservada durante todo o mandato, a fim de que lhes fosse possível a reeleição.
E, se "a Família Ipamerina" e o "Paraná” não mais confiassem em seus representantes eleitos, certamente estes não se reelegeriam.

Outro indicador de que a regionalização era importante foi o conjunto de críticas feitas à tendência de considerar o Brasil como reflexo do que acontecia no Rio de Janeiro e em São Paulo, os grandes centros culturais e econômicos do país. Nesse sentido, o Senador eleito por Goiás, Benedito Ferreira, criticou aqueles que votaram representando a realidade do Rio de Janeiro e São Paulo e não a realidade de suas regiões. Justificando sua crítica, apresentou um quadro para demonstrar que a votação a favor do divórcio não condizia com as necessidades sociais das várias partes do país. Tomando como base o número de desquites registrados em 1973 e o percentual de desquites por região, Benedito Ferreira apontou que mais de $80 \%$ dos processos de desquites aconteceram nas regiões Sul e Sudeste, não refletindo, portanto, a realidade nacional. Além disso, ressaltando a falta de coerência na representação política, o quadro objetivava demonstrar que, enquanto apenas $8,8 \%$ dos casos de desquite ocorreram nas regiões Norte e Nordeste, os votos a favor do divórcio de parlamentares destas regiões somavam $43,3 \%$.

QUADRO 1 - VOTAÇÃO DA EMENDA CONSTITUCIONAL DO DIVÓRCIO EM 15 DE JUNHO DE 1977

\begin{tabular}{|l|c|c|c|c|}
\hline \multirow{2}{*}{ REGIÃO } & \multicolumn{2}{|c|}{ DESQUITES (1973) } & \multicolumn{2}{c|}{ VOTOS DOS DEPUTADOS } \\
\cline { 2 - 5 } & N. ABSOLUTOS & $\%$ & N. ABSOLUTOS & $\%$ \\
\hline NORTE & 92 & 0,7 & 17 & 7,8 \\
NORDESTE & 1032 & 8,1 & 77 & 35,5 \\
SUDESTE & 8448 & 66,2 & 70 & 32,3 \\
SUL & 2579 & 20,2 & 38 & 17,5 \\
CENTRO-OESTE & 601 & 4,8 & 15 & 6,9 \\
TOTAIS & 12752 & 100,0 & 217 & 100,0 \\
\hline
\end{tabular}

FONTE: Senador Benedito Ferreira (1977, p. 1639).

Dentre os grupos de eleitores que freqüentemente enviavam manifestos aos parlamentares, reivindicando o direito de ser efetivamente representado no que tange à decisão sobre a instituição ou não do divórcio no Brasil, um destacava-se. A Igreja Católica pode ser facilmente identificada como um grupo que estava sempre presente, cobrando dos parlamentares posições claras e exigindo fidelidade à "natureza católica" do Brasil. Eram freqüentes as leituras, por parte dos parlamentares, de documentos recebidos de entidades ligadas à Igreja. Muitas dessas entidades representavam oficialmente a Igreja, como no caso do Arcebispo Metropolitano de Curitiba e do Bispo de Divinópolis, que enviaram correspondências ao Parlamento dizendo, respectivamente: "Os Bispos paranaenses, cônscios de suas graves responsabilidades, sobretudo na hora presentes [sic], esperam que os representantes deste grande Estado sejam merecedores do elevado mandato que 
receberam e saibam resguardar a Família da terrível ameaça que pesa sobre ela" (MIKILITA, 1962, p. 576). "Confiamos em nossos deputados. Como legítimos e autênticos representantes do povo mineiro, não poderão destruir os alicerces de nossos lares. O eleitorado de Minas, esta Minas sempre fiel à Igreja, nunca lhes perdoaria tamanha insensatez" (NOBRE, 1966, p. 5) 5 .

O Deputado Alípio de Carvalho, ao declarar seu voto contra a Emenda Constitucional n. 9, de 1977, colocou-se como representante de seus eleitores (ou de parte deles) e porta-voz dos anseios destes, dizendo tê-los consultado sobre como posicionar-se frente à votação da Emenda de cunho divorcista. Nas palavras do Deputado: "Voto contrário ao divórcio, de acordo com a opinião da maioria dos meus eleitores que se manifestaram contra a instituição do divórcio em nosso País, mediante pesquisa que realizei por telegrama enviado a líderes municipais e amigos com os quais sempre tenho contado de forma decisiva em minhas eleições, já por 3 legislaturas, à Câmara dos Deputados" (CARVALHO, 1977, p. 1493).

Se a princípio todos os parlamentares eram "representantes do povo", sendo o povo entendido como o conjunto de eleitores, a referência ao mandato imperativo implica a identificação do grupo mandante, revelando a diversidade escamoteada pela homogeneização implícita no vocábulo "povo". Também delimitando o perfil daqueles a quem representava, o Deputado Antônio Annibelli declarou: "[...] conhecendo profundamente aqueles que me outorgaram o mandato de Deputado Federal, tenho a mais absoluta certeza de que, ao votar contra a emenda constitucional votei exatamente como votaria cada um dos meus eleitores, se a eles fosse facultada a honra de votar nesta Casa. Agi, repito, como legítimo procurador de milhares de brasileiros, cuja formação cristã, respeito à família e às próprias con-

\footnotetext{
5 Parece haver um erro na listagem de discursos no documento disponível no sítio da Câmara dos Deputados, em cuja versão não consta o discurso do Pe. Nobre na página 5. Contudo, na listagem de discursos fornecida pela biblioteca da Câmara o discurso encontra-se presente na página citada, em documento publicado em 28 de abril de 1966, em que o Pe. Nobre lê uma carta do Bispo de Divinópolis. A autora possui cópia impressa do referido discurso, para eventual esclarecimento [nota do revisor.]
}

vicções religiosas, não admitem a dissolubilidade do matrimônio" (ANNIBELLI, 1975, p. 112).

\section{II.3. A Igreja Católica}

A distinção do mandato imperativo está em que "cada Deputado representa uma circunscrição eleitoral ou um determinado grupo que o tenha escolhido, recebendo além disso instruções especiais" (SOUSA, 1971, p. 46). Ou seja, a representação por delegação implica o cumprimento por parte do representante de regras determinadas pelo representado. Sob essa perspectiva, o poder exercido pela Igreja Católica sobre a população e sobre o Estado e as características da afiliação religiosa (que se estabelece por uma crença acrítica do fiel nos preceitos religiosos) apontam a Igreja Católica como mandante que constantemente, nos púlpitos, nos confessionários, nas rádios e nas ruas, por intermédio de padres, bispos e outros discípulos, transmitia suas instruções especiais sobre como seus mandatários deveriam agir em relação ao debate sobre o divórcio.

A presença de muitos representantes diretos da Igreja no Parlamento, sendo importante ressaltar que o líder na luta contra o divórcio foi o padre e Deputado Alfredo de Arruda Câmara, remete à representatividade como modelo de representação política. Sendo parte de um todo (entendido como o conjunto de católicos ou mesmo como a doutrina católica), os deputados e senadores ligados mais ou menos diretamente à Igreja Católica representavam também a si mesmos e aos seus interesses em seus discursos.

A representatividade é expressa na fala do Deputado José Zavaglia quando afirma: "Sr. Presidente, Srs. deputados, através do batismo, nós nos tornamos cristãos; como cristãos somos um sinal aqui na terra e como sinal temos uma obrigação, uma responsabilidade, um dever e um ideal a realizar. Por isso mesmo, porque cristãos, com a graça de Deus, aqui estamos, Sr. Presidente, para cumprir nosso dever, realizar nossos ideais e atender às nossas obrigações da nossa formação moral" (ZAVAGLIA, 1977, p. 2399).

Certamente o grupo dos católicos pode ser apontado como aquele que mais destacou-se como mandante que delegava poderes específicos e limitados aos seus mandatários. Os representantes do catolicismo no Parlamento ressaltavam a legitimidade da Igreja para intervir na defesa da indissolubilidade matrimonial, pois esta teria "por 
obrigação divina a orientação das consciências dos seus fiéis" (FREIRE, 1977, p. 1373). Os limites ou regras da delegação, constantemente reafirmados por cartas, manifestos e mais diretamente nos rituais religiosos, apoiavam-se nas escrituras bíblicas ${ }^{6}$.

Ao afirmar que a aprovação de um projeto divorcista seria "uma afronta a postulados sagrados de fé" (MIKILITA, 1962, p. 576) e que os parlamentares eleitos pelos católicos não poderiam apoiar o divórcio pois estariam "traindo a vontade dos seus representados e solapando os fundamentos da família brasileira" (ZAVAGLIA, 1977, p. 1023), os parlamentares reforçavam a idéia de que todos os católicos deveriam servir a Deus, como mandatários, demonstrando os tênues limites entre a responsabilidade política (civil) e o compromisso religioso.

A atuação da Igreja era legitimada pela referência ao título nacional de "maior nação católica do mundo". Os dados apontando o altíssimo percentual da população católica serviam também para justificar a decisão parlamentar não apenas pelo viés religioso - já que a separação EstadoIgreja data de 1890 - mas, também, pela suposta vontade nacional.

O senador Ruy Santos defende a indissolubilidade do casamento dizendo que o faz "Principalmente por fidelidade ao mandato que recebi de um eleitorado católico. Como todos nós. Se somos mais de $90 \%$ da população brasileira fiéis a Cristo, defendemos o princípio de que o homem não pode separar a quem Deus uniu. E como eu, há muitos entre nós, a maioria - estou certo - que iremos defender a indissolubilidade do casamento. Sem timidez, com convicção. Temos um mandato que nos vem de um eleitorado católico. Não sejamos tímidos. Antes fiéis ao mandato recebido. Há necessidade de se ter firmeza de dizer não às propostas apresentadas" (SANTOS, 1977, p. 1386).

Sob a perspectiva quantitativa, representar o povo significava representar a maioria numérica e, "se $80 \%$ de nosso povo está seriamente comprometido com o cristianismo; e nós somos re-

\footnotetext{
6 É importante esclarecer que nesse momento deixaremos de lado as discussões sobre as possíveis e diferentes interpretações das Escrituras, fazendo referência apenas à leitu-
} ra disseminada pela Igreja Católica dos textos da Bíblia. presentantes desse povo, saímos desse povo, nós, deputados e senadores da República Federativa do Brasil, temos a responsabilidade de representar cristãmente um povo que, em sua imensa maioria, é um povo Cristão" (ARBAGE, 1976, p. 141). A afirmação da existência de uma unidade religiosa no Brasil, onde "todos" seriam católicos, legitimava a posição antidivorcista por si só. A luta contra o divórcio não precisava ser justificada ou fundamentada, bastando a referência ao fato de que a população (os mandantes) era católica e a presunção de que todos os católicos seriam fiéis ao preceito indissolubilista.

A referência à vontade da maioria também era utilizada como argumento de defesa da tese divorcista. Para o Deputado Florim Coutinho, "diante das estatísticas levantadas, a maioria do povo brasileiro - incluindo os casados, os bem casados - é a favor da instituição do divórcio como uma solução necessária para os casos consumados e sem remédio, que viria reerguer lares desfeitos e dar aos filhos novos lares" (COUTINHO, 1971, p. 6457).

É válido anotar que a busca da legitimação a partir da representação da maioria, ao mesmo tempo em que remete à representação por delegação, também coaduna com o ideal político de preservação da confiança, já que é esta maioria quem, em última instância, elege deputados e senadores.

A idéia de que os divorcistas, ao contrariarem o desejo da maioria, estariam rompendo com o pacto de confiança estabelecido entre eles e os seus mandantes no momento da eleição era freqüentemente ressaltada pelos antidivorcistas, servindo como argumento para coibir aqueles parlamentares que ainda não haviam se manifestado ou aqueles que, apesar da tendência divorcista, pudessem temer a represália popular.

A eficácia da represália popular aparece nos discursos na discussão sobre possíveis diferenças nos resultados das votações abertas ou secretas. Segundo o Deputado Lauro Rodrigues, "o Congresso Nacional, por sua maioria, está claro, é divorcista confesso e, por maioria discreta, também eis que muitos dos Senhores Deputados ou Senadores a quem tive ocasião de ouvir no preâmbulo das votações, me confessaram que se o voto fosse secreto votariam favoravelmente ao divórcio mas não em votação a descoberto" (RODRIGUES, 1975, 2667). 
No mesmo sentido, uma circular do Bispo da Paraíba lida em plenário por Arruda Câmara ainda na década de 1960 também tinha por objetivo pressionar os parlamentares no sentido de manter o voto aberto na questão do divórcio e, assim, expor os divorcistas ao crivo popular: "Acresce ainda que os divorcistas embora já tenham sido derrotados neste sentido, vão, de novo, pleitear votação secreta para tais projetos, em um acintoso desrespeito à família brasileira que, nesta grave conjuntura, tem o direito de saber quais as idéias e convicções de seus Representantes escolhidos sob promessa de que defenderiam sempre, neste particular, sobretudo, os sagrados direitos naturais e tradições cristãs do nosso povo" (CÂMARA, 1962, p. 627).

O repúdio à votação secreta de quaisquer projetos com fins divorcistas fundamentava-se no dever de responsabilidade atribuído à representação. Nesse sentido, a representação é entendida, sobretudo, como relação de confiança, em que, apesar de ter autonomia para decidir (podendo inclusive apoiar a realização de votação secreta) o parlamentar tem a obrigação de prestar contas à sociedade, especialmente ao seu eleitorado, que, em uma próxima eleição, decidirá se manterá a fidúcia ou se a depositará em outro candidato.

Mas, como a maioria não é homogênea, não garantindo por si só a reeleição de nenhum parlamentar, a resposta de divorcistas para o argumento de que é função dos parlamentares representar a maioria é justamente a de que as "minorias" também precisam e merecem ser representadas, a fim de que haja uma relação mais igualitária na sociedade e esta esteja refletida no Parlamento.

O pluralismo religioso e a necessidade de defendê-lo foram exaltados por Nelson Carneiro, que se colocava como representante da minoria não-católica dizendo, "nesses vinte e cinco anos de luta, nunca, Sr. Presidente, me coloquei contra a Igreja Católica. Sempre respeitei sua posição em defesa do vínculo conjugal, mas em um País onde existem muitas religiões e em que nem todos são católicos era, também, preciso, como representante de todo esse povo, falar por aqueles que não obedecem aos ditames dessa Igreja" (CARNEIRO, 1975, p. 432).

É interessante observar a cautela com que os divorcistas referiam-se à Igreja Católica. Apesar de buscarem romper com um dogma católico, a indissolubilidade do casamento, os parlamentares divorcistas fogem de qualquer embate com a Igreja, colocando-se, inclusive, muitas vezes, também como católicos ou simplesmente devotos de Deus. Esse cuidado por parte daqueles que lutaram pela adoção do divórcio no Brasil pode ser tomado como uma estratégia política. Diante do poder hegemônico da Igreja, não era produtivo aos divorcistas adotar táticas de enfrentamento. Assim, não havia, nos quase 900 discursos proferidos sobre o divórcio durantes as décadas de 1950, 1960 e 1970, nenhum que defendesse francamente o enfraquecimento da Igreja ou a ruptura de suas bases fundantes, assim como também não havia nenhum que propusesse uma grande ruptura do modelo de organização familiar e, conseqüentemente, dos papéis sexuais. Apesar de, a partir do início da década de 1970, serem mais freqüentes as referências à necessidade de flexibilização da Igreja para que esta acompanhasse as transformações sociais conforme indicara o Vaticano II, ainda assim a instituição era absolutamente preservada no embate político. Uma demonstração disso estava na forma como Nelson Carneiro iniciou a defesa de um de seus projetos de cunho divorcista (Projeto de Lei n. 1810/1960): "Sr. Presidente, começo elevando o meu pensamento a Deus, rogando-lhe que me inspire na sustentação que vou fazer perante esta Casa, da constitucionalidade, da conveniência e da legitimidade do projeto" (CARNEIRO, 1962, p. 1670).

Além do não enfrentamento em relação à Igreja Católica, conforme vimos anteriormente, outro limite imposto à atuação dos divorcistas estava na previsão constitucional da indissolubilidade ${ }^{7}$. Visando escapar do julgamento de inconstitucionalidade inescapável aos projetos divorcistas, os parlamentares apresentavam projetos dizendo-os não de divórcio, mas de ampliação das hipóteses da já aceita anulação de casamento. Tal estratégia, visando "obter uma recepção positiva na cena política”, é apontada por Araújo como um meio legítimo de efetivação da representação. De acordo com o autor: "No julgamento do desempenho dos representantes, é claro que se deve considerar a capacidade deles de levar à cena pública as queixas sociais dos diferentes estratos/grupos/classes da comunidade e então tensionar as instituições políticas e seus pro-

\footnotetext{
7 As Constituições Federais de 1934, 1937, 1946 e 1967, assim como a Emenda Constitucional n. 1, de 1969, resguardavam a indissolubilidade do casamento.
} 
cessos decisórios. Porém, o julgamento tem de atentar igualmente para a capacidade da representação de reelaborar as queixas, torná-las mais reflexivas, dando-lhes a forma adequada para obter uma recepção positiva na cena pública. A avaliação a ser feita nesse ponto é muito complexa, porque os atores políticos sempre deverão procurar um delicado equilíbrio entre a preservação de sua interface social e a manutenção da cena pública na qual encontram seus adversários políticos. Os representantes buscam, assim, uma dupla cumplicidade: com seus representados, sem dúvida, mas também com seus próprios adversários na cena pública" (ARAÚJO, 2006, p. 14).

O que quero ressaltar ao discutir mais profundamente a questão da representação política é, sobretudo, a importância dos limites do dizer (e do agir) próprios do cenário político. $\mathrm{O}$ tratamento da representação política a partir dos discursos é um meio útil para problematizarmos a fonte de pesquisa, já que as peculiaridades do universo político são-lhe intrínsecas. Os limites, estabelecidos dentro do jogo político em um determinado espaço e tempo, podem ser apontados como delimitadores também da representação, que ganha significados diferentes conforme possa ser mais extensiva ou menos.

Enquanto Nelson Carneiro, apesar de enfatizar seu respeito à Igreja Católica e dizer-se católico praticante, relacionava a sua posição a favor do divórcio com a não representação de católicos, Arruda Câmara também delimitava sua representação, colocando-se, como antidivorcista, como não representante de um determinado grupo de pessoas. Exigindo que os parlamentares posicionassem-se de acordo com o que explicitaram em suas campanhas eleitorais, Arruda Câmara explicou: "Porque, se eles tivessem dito que vinham votar o divórcio, talvez o único que fosse eleito seria, como foi, o Sr. Nelson Carneiro, pelas desquitadas de Copacabana e pelos burgueses desejosos de mudar de mulher a cada mês ou a cada ano, conforme suas paixões, seus apetites e seus interesses" (CÂMARA, 1961, p. 9794).

Além de delimitar sua área de representação, excluindo as "desquitadas de Copacabana" e os "burgueses desejosos de mudar de mulher a cada mês ou a cada ano", o mesmo parlamentar expressava um pensamento absolutamente vinculado à sua crença religiosa. Arruda Câmara alertava os seus companheiros do Parlamento sobre a exis- tência e a força de Deus. O Deputado deixava claro que, para além de haver a preocupação em garantir a confiança do eleitor, existia um mandante que detinha o poder supremo de observação do que era realizado pelos mandatários e ao qual se devia satisfação sobre os atos praticados não apenas durante o mandato parlamentar, mas durante toda a vida. No final do discurso supracitado, Arruda Câmara ressaltou: "Sr. Presidente, antes de terminar meu discurso, devo dizer, alertando a consciência dos Srs. deputados e dos Srs. Membros da Comissão de Justiça que, se aprovarem esse projeto cometerão um crime contra a Nação brasileira e, sobretudo, desobedecerão às ordens do Supremo Juiz. É que, acima desta cátedra, acima desta tribuna da representação popular, representação do povo, de que emanam os poderes, está a cátedra e a tribuna do Supremo Juiz, do Supremo Legislador, pelo qual, como dizem as escrituras, governam os poderosos e decretam os legisladores as leis justas. E eu e vós daremos conta a esse Juiz. Não tenhamos dúvida, não nos iludamos. Será cedo ou tarde, mas compareceremos perante o Juiz inagelável, ante o qual não há o manto diáfano da fantasia para ocultar os monstros, os pecados e os atentados à família brasileira" (idem, p. 9794).

A representação aqui, ao mesmo tempo em que se refere à delegação também refere-se à confiança, já que fica evidente o livre arbítrio do mandatário em relação às suas decisões na Terra, só havendo a sujeição às conseqüências pela quebra da fidúcia no momento do Juízo Final (a próxima eleição ou a passagem ou não para a vida eterna). Além disso, por tratar-se de um trecho de discurso proferido por um lídimo representante da Igreja Católica, Monsenhor Alfredo Arruda Câmara, a representação também se configura como representatividade, sendo o representante parte do todo a que entende representar.

Como se pode notar, a tentativa de configurar os discursos como sendo baseados no modelo de representação como delegação exige sempre alguns retoques e adaptações. Apesar de muitas vezes os políticos colocarem-se como fiéis representantes de determinados grupos (seja do partido político, seja dos seus eleitores "individualmente", seja da região que o elegeu, seja da doutrina religiosa que o promoveu etc), não há como abstermo-los de observar que eles mantinham sua autonomia, ou, pelo menos, tinham assegurados 
os meios para exercê-la. O que se pode notar é que a opção por usufruir ou não dessa autonomia dava-se muito mais por questões relacionadas à afinidade de interesses ou o desejo ou necessidade de reeleição do que propriamente por submissão política. A própria "autovitimização" dos parlamentares, quando se colocavam como fiéis delegados de seus representados, pode ser apontada como uma estratégia política para escamotear ou mesmo esvaziar o controle da sociedade sobre o seu mandato.

\section{A REPRESENTAÇÃO COMO CONFIANÇA}

O modelo de representação como relação de confiança fundamenta-se justamente na idéia de que o representante preserva sua autonomia, não estando vinculado a nenhuma diretriz previamente estabelecida pelo representado. Nas palavras de Sousa, "O representante [...] é a pessoa a quem cabe praticar certos atos em nome de uma sociedade, e isto em virtude da posição que ocupa na estrutura da comunidade, sem precisar receber instruções específicas, nem depender da aprovação ou possível impugnação de tais atos" (SOUSA, 1971, p. 19). O chamado mandato fiduciário não vincula diretamente o representante a qualquer interesse do representado, mas, fundado na confiança, depende da manutenção desta para perdurar. A representação como relação de confiança "atribui ao representante uma posição de autonomia e supõe que a única orientação para sua ação seja o interesse dos representados como foi por ele percebido" (COTTA, 1992, p. 1102).

Essa concepção de representação, que defende a independência do representante em relação aos representados, é teorizada por Edmund Burke em seu "Discurso aos eleitores de Bristol", de 1774. De acordo com Burke, o representante deve aos seus eleitores devoção aos seus interesses antes que à sua opinião. Uma vez que a relação de cada parlamentar não está circunscrita à cidade que o elegeu, mas à nação que, por sua vez, é parte de um império, ele não representa aqueles que o elegeram. $\mathrm{O}$ autor descreve "o papel do representante como um 'trabalho de razão e de juízo' a serviço do 'bem comum' e não do simples 'querer' e dos 'preconceitos locais"” (ibidem).

Discutindo o quanto o mecanismo eleitoral pode, de fato, tornar mais representativas as instituições da democracia, Manin, Przeworski e Stokes (2006) distinguem o que chamam de “implementação do mandato" da representação política em si. De acordo com os autores, em determinados casos, visando não romper o vínculo de confiança, os parlamentares abrem mão de atuar para o bem-estar dos eleitores escolhendo cumprir cabalmente a plataforma que os elegeu (ou seja, aquela que foi "aprovada" pelos eleitores). Nesses casos, os autores afirmam que "o mandato será implementado, mas os políticos não atuarão de forma representativa": "Os representantes podem ora executar políticas que melhoram o bem-estar dos eleitores por meio de desvios do mandato, ora ser obedientes ao mandato, mesmo se acreditarem que sua implementação não será melhor para os eleitores. Se a implementação do mandato não é o melhor que o governante pode fazer, então é difícil acreditar na ameaça de punição para quem se desvia do mandato. Os eleitores podem não gostar de governantes que traem suas promessas, mas não punirão os políticos que beneficiam os eleitores mediante desvios do mandato" (idem, p. 6).

Pitkin ressalta que não importa quantos pensadores tomem posição em um lado ou no outro, "a polêmica sobre o mandato e a independência é um daqueles debates teóricos infindáveis que nunca parecem se resolver" (PITKIN, 2006, p. 30). A questão pode ser sintetizada na seguinte escolha dicotômica: "um representante deve fazer o que seus eleitores querem ou o que ele acha melhor?" (ibidem).

De acordo com Souza (1971, p. 43), quando a representação efetiva-se, "o Deputado não representa os eleitores, como se dava no tempo do 'mandato imperativo', mas a própria Nação e a vontade nacional se corporifica na vontade de seus representantes". Desse modo, segundo o mesmo autor, "a representação não tem, pois, por objeto, delegar a certos órgãos o poder de interpretar os votos ou as aspirações da coletividade. Ela tem por fim autorizar estes órgãos a dizer o que quer a nação, isto é, a ser sua vontade e sua voz. Em suma, a representação é criadora da vontade nacional" (idem, p. 46).

Esse era o entendimento do Senador Benedito Ferreira quando ressaltou: "Cientes, pois, da gigantesca tarefa a que nos propusemos, de ser os legisladores do Brasil nesta difícil fase que atravessa a humanidade, neste período em que falece ao homem - em todas as latitudes da terra - quaisquer perspectivas mais animadoras, estamos mais que qualquer outra geração de legisladores 
que nos antecedeu - na obrigação de buscar em Deus toda a inspiração, todo o apoio, para decidir, para legislar, não de acordo com a chamada 'vontade popular', mas em consonância com as reais necessidades da nossa gente, especialmente das futuras gerações, sob pena de não alcançarmos nas páginas da História - se é que sobreviveremos como humanidade para tê-la escrita - a culminância da vida pública, que é o título de estadistas.

Não me acode à memória, mas li, em certa oportunidade, uma definição sobre as figuras dos 'políticos' e dos que, mesmo arrostando a impopularidade, vale dizer, despreocupados em ser agradáveis, sem a preocupação de cortejarem momentâneas vontades populares, atingiram o grau de estadistas, dando ao seu povo, não o que pedia, mas aquilo que realmente necessitava" (FERREIRA, 1975, p. 4804).

O entendimento de que os parlamentares são "escolhidos por suas qualidades distintivas, [...] são colocados em uma posição que lhes permite compreender melhor as questões públicas, graças às informações a que têm acesso, às discussões no próprio parlamento e à especialização na tarefa legislativa" (ibidem), atribui-lhes competência para distinguir a vontade popular do bem para a população. Nesse aspecto, a representação como confiança distancia-se da delegação, pois ao invés de o político seguir as regras prescritas pelos seus eleitores, ele deve até mesmo ir contra elas, se este for o melhor caminho para o "bem-comum".

Sob essa perspectiva, o primeiro embaraço está em pensar a diversidade de significados que podem ser atribuídos a esse "bem-comum". A dificuldade fica explícita nas palavras do Deputado Daniel Faraco, que, ao mesmo tempo em que delegava aos parlamentares a função de intérpretes da "vontade do povo", já apontava o que entendia ser a vontade deste povo e, mais do que isso, definia qual a interpretação "mais correta". De acordo com Daniel Faraco, "nossa missão é a de interpretar [sic] da vontade do povo. A nossa missão, o nosso dever é respeitar os princípios, as tradições e os supremos interesses do povo brasileiro e são estes interesses que exigem seja mantida a indissolubilidade da família, que o divórcio seja fulminado e que o projeto infeliz do Deputado Nelson Carneiro seja rejeitado pela Câmara dos Deputados (FARACO, 1952, p. 1365).
Da mesma forma, ao reproduzir um trecho de uma carta escrita pelo ex-Deputado Carlos de Britto Velho, Geraldo Freire ressaltava a função parlamentar de galgar o bem-comum para logo em seguida delimitar esse conceito excluindo o que denominou "bens privados". Na carta lia-se: "As leis são feitas para contribuírem na efetivação do bem comum, do bem geral, do bem da sociedade, e não para atenderem alguns bens privados, por mais respeitáveis que sejam, por mais comovedores que se nos afigurem" (FREIRE, 1977, p. 1334). Na argumentação do Deputado Geraldo Freire, os interesses daqueles que, infelizes no casamento, desejavam a instituição do divórcio deveriam ser entendidos como "bens privados", opostos ao "bem-comum".

O significado atribuído pelo parlamentar ao "bem-comum" vai ser produto de sua visão de mundo, refletindo não apenas suas idéias sobre o divórcio, mas todo um conjunto de pensamentos, práticas e comportamentos que norteiam sua forma de ver e agir sobre as coisas em geral. Essa lente utilizada para ver o mundo, por sua vez, é uma lente produzida socialmente, a lente da cultura. Como produto cultural reflete códigos e normas compartilhados por um grupo. Assim, por mais que os parlamentares tentassem colocar-se como representantes do todo (no sentido do bemgeral), neutralizando sua posição, eles representavam efetivamente uma parte, a parte em que eles estavam também inscritos e muitas vezes a única parte que conseguiam enxergar. Essa é uma forma praticamente indissociável de vinculação representante-representado. Mesmo gozando de autonomia, esta está a priori limitada, ainda que seja simplesmente pela visão - com tendência etnocêntrica - de mundo do parlamentar, que corresponde à visão de um grupo e não de todos.

Esse comprometimento da visão transparece também na fala do Deputado Fernando Ferrari que, ao dizer que o legislador deveria representar a nação (como um todo), já excluiu o "grupo dos infelizes" no casamento, o grupo dos que desejavam o divórcio, privilegiando o outro grupo, o dos que não sofriam de incompreensão e desajustamento. Nas palavras do Deputado: "Entendo que ser político é ser soldado da Pátria, estando a seu serviço e, como tal, deveremos votar e agir como legisladores da nacionalidade e não deste ou daquele grupo social, atingido em determinado momento pela incompreensão ou pelo desajustamento" (FERRARI, 1952, p. 5174). 
Além dessas limitação e vinculação inerentes à própria visão sobre as coisas, no mandato livre "o representante não está preso às preferências expressas de seus constituintes, mas idealmente deve decidir da forma que eles decidiriam caso dispusessem das condições - tempo, informação, preparo - para deliberar" (MIGUEL, 2005, p. 29). O vínculo representante-representado faz-se presente, condicionando a autonomia do representante.

Mas cabe aqui pensar se essa mesma situação não ocorre no mandato por delegação. Conforme vimos anteriormente, quando os parlamentares colocavam-se como representando seus eleitores, eram os próprios parlamentares que decidiam quem eram seus eleitores e mesmo quais eram os eleitores mais importantes. Vale relembrar a fala do Deputado Alípio de Carvalho, reproduzida anteriormente, quando declarou seu voto contra a Emenda Constitucional n. 9, de 1977. A consulta a "líderes municipais e amigos" justificava sua posição e legitimava, segundo o Deputado, sua função de representante. Mas será que esses foram seus únicos eleitores? Ou mesmo, será que foram os que garantiram sua eleição? A ausência de um estudo mais aprofundado não nos permite chegar a conclusões precisas, mas é possível apontar para a frouxidão em que está inscrita a delegação, ficando muitas vezes a cargo do político delimitar ou interpretar a quem representa e o que desejam seus representados.

Essa "liberdade" do parlamentar para interpretar e significar os interesses de seus possíveis representados é apontada pelos estudiosos como uma porta aberta para a não representação política, mas sim à representação pessoal. A idéia de que "sem os freios e incentivos que oferece a possibilidade de imposição de sanções, tanto positivas quanto negativas, pelo povo comum, os detentores do poder decisório dificilmente resistiriam à tentação de prover seu benefício particular, legislando em causa própria ou, então, cedendo à corrupção" (idem, p. 35), faz que cada vez mais se construam mecanismos de controle que garantam o vínculo dos representantes com seus representados. De acordo com as discussões contemporâneas travadas no campo da teoria política e, mais especificamente, da teoria da democracia, um mecanismo apontado como capaz de regular essa vinculação é a chamada "accountability". "A accountability diz respeito à capacidade que os constituintes têm de impor sanções aos governantes, notadamente reconduzindo ao cargo aqueles que se desincumbem bem de sua missão e destituindo os que possuem desempenho insatisfatório. Inclui a prestação de contas dos detentores de mandato e o veredicto popular sobre essa prestação de contas" (idem, p. 27). A accountability é apontada como um mecanismo que possibilita um maior controle dos governados sobre os governantes, promovendo a representação de maneira mais ampla e complexa do que o simples mecanismo eleitoral.

A análise dos debates parlamentares travados durante as décadas de 1950, 1960 e 1970 sobre o divórcio evidencia quão presente estava, para os parlamentares, a idéia de que, ao mesmo tempo em que gozavam de autonomia para decidir sua posição sobre a instituição ou não do divórcio no Brasil, precisavam preocupar-se com a necessidade de prestar contas à população sobre seu posicionamento e submeter-se, no momento das eleições, ao veredicto popular em relação a esse posicionamento.

Essa noção foi explicitada pelo Deputado Luiz Garcia quando afirmou, "somos, aqui, legisladores. Estamos lealmente votando, mas não apenas dando o nosso voto pessoal. Somos portadores de um mandato e temos contas a prestar não a determinados grupos, mas ao eleitorado, que mandou a esta Casa seus representantes e é natural interessado em qualquer reforma substancial, principalmente em matéria de família" (GARCIA, 1952, p. 7200).

Expressões como: "o Povo, na sua sabedoria, vai nos julgar, pelo Bem e pelo Mal feitos" (COUTINHO, 1971, p. 6457) ou "Temos de manifestar realmente os nossos pensamentos, para que $[. .$.$] aqueles que [...] para cá nos mandaram$ possam também aquilatar a nossa responsabilidade" (LIMA, 1975, p. 2376) eram freqüentemente incorporadas aos discursos. O que chama a atenção é o tom de ameaça em que estavam mergulhadas essas colocações. A idéia de que o povo estava observando tudo o que era feito para depois "julgar" e, mais do que isso, "condenar" os parlamentares no momento das eleições, configurava mais uma relação arbitrária do que um vínculo de confiança. De acordo com a professora do Departamento de Ciência Política da Universidade de Columbia, Nadia Urbinati, uma teoria democrática da representação deve "envolver a idéia de que o povo soberano conserva um poder ne- 
gativo que lhe permite investigar, julgar, influenciar e reprovar seus legisladores" (URBINATI, 2006, p. 208; grifos no original)

Conforme visto anteriormente, os antidivorcistas utilizavam o argumento de que, por estarem supostamente indo contra a vontade da maioria da população brasileira (apontada como católica), os divorcistas estariam rompendo com o vínculo de confiança, ficando muito provavelmente marcados pelos eleitores como "traidores" ou mal executores de seus mandatos. Além disso, os antidivorcistas freqüentemente reiteravam a necessidade de que os parlamentares deixassem bem claras suas respectivas posições ante a questão do divórcio, lutando veementemente contra qualquer votação secreta de projetos de cunho divorcista, alegando ser a "transparência" da votação um elemento necessário para que o eleitor tomasse conhecimento sobre o posicionamento dos políticos e o pudesse avaliar.

Nesse sentido, o Deputado antidivorcista Pe. Nobre declarou: "Eu, mesmo que o voto fosse secreto, abriria a manifestação de minha opinião, pois acho que o eleitorado que nos enviou a esta Casa, ao tocante a problema tão grave e de tamanha responsabilidade social, merece nossa definição clara, limpa e pública, para que possamos desempenhar, daqueles que nos elegeram, o papel que nos conferiram" (NOBRE, 1975, p. 1837).

A "transparência" também era referenciada quando alguns parlamentares defendiam a necessidade de os candidatos manifestarem sua posição em relação ao divórcio no momento das eleições. Nesse sentido, Geraldo Freire questionava: "Por que não fazemos primeiro a nova campanha eleitoral, expondo ao eleitorado brasileiro, para que ele não seja apanhado desprevenido, as nossas idéias? Quem é divorcista, que pregue a sua bandeira; quem é contra o divórcio, que o diga. E o eleitor escolherá" (FREIRE, 1977, p. 1430). O manifestar-se antes das eleições era assim apontado como um meio de legitimar as futuras posições no Parlamento e, conseqüentemente, uma forma de legitimar a própria representação. Dessa forma, o que os antidivorcistas defendiam é que apenas aqueles que se apresentassem como a favor do divórcio em suas campanhas políticas, poderiam, se eleitos, defender com convicção as propostas divorcistas.

O Deputado Nelson Carneiro chamou atenção para um aspecto que, ao mesmo tempo em que tornava opaca a pretendida transparência nas transações de representação, revelava como o recurso a discursos inflamados e freqüentes (sob a alegação de que se quer promover informação à população) podia ser utilizado como um instrumento de manipulação dos eleitores. De acordo com Nelson Carneiro: "Antigamente, na Velha República, compreendia-se a comodidade do Deputado, pois ele precisava apenas impressionar o Governador, que era quem, em última análise, o elegia. Hoje, porém, o Deputado tem que vir constantemente à tribuna para prestar contas dos seus atos, dia a dia, ao seu eleitorado. Deputado que não fala é Deputado que não consegue, em regra, apoio e o voto dos seus correligionários nas eleições futuras. Deputado que não está no plenário gritando, discutindo, não contará com a simpatia do eleitorado que o escolheu" (CARNEIRO, 1959, p. 6837).

A observação do Deputado pode ser apontada como um dos fatores que compromete a accountability. A idéia de que é necessário que o parlamentar faça-se presente, mostrando ao seu eleitorado que está "trabalhando", corrobora a tese de que a população, de um modo geral, não tem acesso a informações sobre as atividades parlamentares senão por intermédio dos próprios parlamentares. Ora, se são os próprios interessados os principais transmissores das informações, é certo levantar a hipótese de que os mesmos "dourem a pílula" antes de entregá-la aos seus eleitores. Esses mecanismos ofuscam a pretendida transparência na representação. Citando Hanna Pitkin, Urbinati aponta que a linguagem do discurso político, como a do discurso moral, "deve ser suficientemente estável para que o que um homem diga realmente consista na tomada de uma posição, realmente diga-nos algo a seu respeito" (URBINATI, 2006, p. 208; grifos no original). Essa estabilidade dos discursos seria um importante indicativo de transparência, um elemento necessário à accountability, à representação e à democracia.

Quando Nelson Carneiro salientou que o Deputado tem que estar "no plenário gritando e discutindo" para garantir a "simpatia do eleitorado que o escolheu", ele apontou que a forma pode sobrepor-se ao conteúdo, ou seja, independentemente da natureza das idéias que são defendidas ou combatidas, o que conquista o eleitor é a forma como são expostas ("no plenário gritando e discutindo"). 
Assim é que nos deparamos com um dos graves problemas para o exercício da accountability, a comprometida cultura política nacional. Ao discutir dilemas e alternativas da representação política, o Cientista Político Luis Felipe Miguel afirma que "as esperanças depositadas na accountability (vertical) [...] não encontram mais do que uma pálida efetivação na prática política. A capacidade de supervisão dos constituintes sobre os seus representantes é reduzida, devido a fatores que incluem a complexidade das questões públicas, o fraco incentivo à qualificação política e o controle sobre a agenda" (MIGUEL, 2005, p. 27).

Em um país como o Brasil, marcado pela desigualdade social, a dificuldade e a desigualdade no acesso à informação são fatos incontestes, e, além disso, é clara a desigualdade na oportunidade de participação (tanto direta quanto indireta). Quando acima dissemos que os parlamentares representavam a parte e não o todo, é preciso perceber que parte é esta, de qual parcela da população vieram os próprios parlamentares e a sua visão de mundo.

O que ocorre, então, é que a pretensão de representar toda a nação, sem concentrar-se em interesses individuais ou de grupos, não se realiza. Os parlamentares, quando criavam a "vontade nacional", reproduziam a vontade de determinados grupos, e, normalmente, a vontade de grupos dominantes, grupos que por deterem poder político tinham voz ativa nas decisões de agenda e na cobrança das prestações de contas. Da mesma forma, conforme vimos anteriormente, na representação como delegação também costumavam prevalecer os interesses dos grupos dominantes. Assim, "um dos principais problemas identificados na representação política contemporânea diz respeito à sub-representação de determinados grupos sociais. $\mathrm{O}$ grupo dos governantes, em relação ao conjunto da população, tende a ser muito mais masculino, muito mais rico, muito mais instruído e muito mais branco - uma observação que vale para o Brasil e para as democracias eleitorais em geral" (MIGUEL, 2005, p. 34).

Essa identidade entre os que compõem o grupo de governantes chama a atenção no debate sobre o divórcio e merece destaque em relação a dois aspectos. Primeiro, porque a maioria esmagadora dos autores de discursos sobre casamento, família, separação e divórcio era constituída de homens (apesar de o papel da mulher na família ser um argumento recorrente tanto para defender quanto para repudiar o divórcio). Além disso, tanto divorcistas quanto antidivorcistas defendiam o mesmo modelo de família, que implicava a manutenção das relações desiguais entre os sexos, entre outras coisas. A diferença é que, enquanto os antidivorcistas fundamentavam a defesa dessa família na indissolubilidade do casamento, os divorcistas defendiam-na pela via do novo casamento.

O segundo aspecto que precisa ser destacado é o fato de que, apesar de estarmos tratando das décadas de 1950, 1960 e 1970, período em que os meios de comunicação alardeavam a "ameaça comunista" no Brasil, o que subentendia a existência significativa de tal corrente de pensamento, as idéias comunistas não estavam presentes nos debates sobre o divórcio. Pelo contrário, os discursos traziam uma enorme rejeição, tanto de antidivorcistas quanto de divorcistas, a qualquer semelhança com os comunistas. Uma demonstração disso estava na troca de acusações que antidivorcistas e divorcistas faziam entre si sobre as estratégias utilizadas na defesa e divulgação de suas respectivas teses. Os antidivorcistas comparavam a propaganda do divórcio com a agitação comunista, afirmando que "uma e outra fundam-se no materialismo e partem de pequenos grupos ativos e ruidosos, radicados nas cidades maiores, enquanto a população se conserva alheia e contrária à demagogia estéril e nefasta promotora da subversão da ordem social e da ordem familiar" (FARACO, 1962, p. 1477). Ao mesmo tempo, os defensores do divórcio utilizavam argumento muito semelhante, também criticando a estratégia antidivorcista por sua comparação com a tática comunista. Nas palavras de Nelson Carneiro: "Sei que já estão começando a chegar aqui alguns abaixo-assinados feitos nas portas das Igrejas, por meninos, por senhoras fanáticas, que vão assinando, cinqüenta, cem vezes, nomes diferentes, para empanturrar os Anais da Câmara com esses protestos inexpressivos. Esta é uma tática comunista muito velha, e muito conhecida dos que integraram passadas legislaturas" (CARNEIRO, 1959, p. 9061).

$\mathrm{O}$ que interessa ressaltar neste momento são as ausências, os silêncios, a falta daqueles que não estavam representados no cenário político (como as mulheres e os comunistas) e que, por essa razão, não tiveram seus interesses atendidos. 
A sub-representação ou mesmo a ausência de representação de determinados grupos sociais corresponde à não representatividade destes na representação política.

\section{A REPRESENTAÇÃO COMO "ESPELHO"}

O modelo de representação como "espelho" "concebe o parlamento como uma espécie de mapa, no qual se vê a imagem perfeita, embora em tamanho reduzido, da sociedade" (MIGUEL, 2005, p. 35). "Diferentemente dos dois primeiros [modelos de representação] é centrado mais sobre o efeito de conjunto do que sobre o papel de cada representante. Ele concebe o organismo representativo como um microcosmos que fielmente reproduz as características do corpo político" (COTTA, 1992, p. 1102).

O modelo de representação como representatividade apresenta-se como uma proposta de garantia da participação política dos diferentes grupos sociais. Para tanto, são apontados como mecanismos de promoção da participação política a seleção aleatória dos governantes e (ou) a reserva de vagas para grupos marginalizados. Contemporaneamente, a prática de exigência de cotas de mulheres nas instituições públicas, incluído aí o Parlamento, segue essa linha de entendimento, garantindo, por meio da reserva de vagas, a participação política das mulheres, assim como de outros grupos tradicionalmente excluídos do poder. A identidade entre representante e representados é apontada como um meio de suscitar a participação ativa e inclusiva do eleitorado no debate político, mantendo conectados sociedade civil e esferas públicas. Young (2006) ressalta, entretanto, as dificuldades da relação identitária, uma vez que os indivíduos podem identificar-se em relação a alguns aspectos e, entretanto, divergir em relação a outros, o que corresponderia a ruídos na representação.

Sem entrar na discussão sobre a potencialidade e os limites desse modelo, vejamos como pensar a representatividade na representação dos parlamentares durante os debates sobre o divórcio travados de 1951 a 1977 no Congresso Nacional brasileiro. Recuperando um pouco o que já trabalhamos no decorrer deste ensaio, fica claro que o grupo dos católicos é o que mais se destacava como participante direto no debate. Os católicos, tanto os que tinham vínculos formais com a Igreja como os que não os tinham, muitas vezes fala- vam abertamente como católicos, pautando seus argumentos justamente nesta identidade religiosa.

O problema da representatividade, no caso prático do debate sobre a instituição do divórcio no Brasil, está no fato de que ela estava isolada, não era parte do sistema. Isso significa que apenas um determinado grupo estava representado, havendo a exclusão dos demais, o que, sob certo ponto de vista, esvaziava o ideal de representação política. É bastante provável que outros parlamentares também discutissem e votassem de acordo com interesses seus (ou de grupos dos quais faziam parte). Seria o caso, por exemplo, de todos aqueles que, defendendo a instituição do divórcio no país, alegando que os casais infelizes no casamento dela necessitavam para resolver sua situação familiar, desejassem regularizar a sua própria situação de concubinato ou de desquite por meio do divórcio. Todavia, o que a análise do debate evidencia é que vários grupos não estavam representados, como era o caso das mulheres, dos não católicos, dos desquitados, dos comunistas ou socialistas, dentre outros, o que, certamente, contribuiu para que a proposta de introdução do divórcio na legislação brasileira tenha tido uma tramitação longa e demorada.

\section{CONCLUSÕES}

A análise dos discursos parlamentares permite concluir que os políticos refletem, em maior ou menor profundidade, sobre seu papel como representantes políticos. Ora justificando sua posição frente a uma determinada questão, ora buscando legitimar suas proposições e votos, ora simplesmente procurando fortalecer o vínculo que os liga aos seus eleitores, deputados e senadores expressam representações sobre o papel que exercem dentro do Congresso Nacional, mobilizando, na prática política, as diferentes possibilidades do conceito de representação política construídas no âmbito da teoria política.

A múltipla significação que pode ser atribuída ao termo representar pré-anuncia a complexidade da questão. Representar é corriqueiramente identificado com a representação teatral, com fingir ou falsear; ou entendido como fazer as vezes de, ocultar-se em nome do representado ou mandatário; ou ainda, como conceito sociológico (representações sociais), referindo-se a "categorias de pensamento através das quais determinada sociedade elabora e expressa sua realidade" (ARCHANJO, 2006, p. 7). 
Os modelos de representação política descritos pela bibliografia precisam ser analisados levando em conta a dinâmica da política contemporânea, assim como a própria dinâmica social. Não se encontra na prática política a "pureza" que os conceitos apresentam. O que se vê na prática é a mistura (não consciente) dos modelos teóricos, sendo que a necessidade de expressar a importância da manutenção do vínculo com o eleitor está sempre presente.

O contexto em que se inscrevem a Câmara dos Deputados e o Senado Federal, cenário da política por excelência, apresenta duas faces: por um lado, limita o dizer e o fazer parlamentar, configurando-se como um espaço de expressões conservadoras, lugar de expressão daquilo que publicamente pode ser expresso; por outro lado, como sítio em que se reúne o conjunto de deputados e senadores eleitos pelo voto popular, presume a legitimidade do que é dito, ou seja, não há como não relacionar as falas parlamentares com a polifônica "voz do povo". A singularidade e a pluralidade, o homogêneo e o heterogêneo, o uníssono e o polifônico. A prática parlamentar exige a mediação entre essas possíveis oposições, enquanto a análise dos discursos políticos exige a observância das peculiaridades da fonte de pesquisa. É preciso não perder de vista que as falas dos políticos são, antes de tudo, produtos do contexto em que estão inscritas, ou seja, os discursos são forjados pelo significado atribuído pelos parlamentares à sua função de representantes políticos.

Ao discutir a questão da representação política relacionando a teoria política com representações expressas por parlamentares (deputados e senadores) sobre o seu papel de representantes políticos, o presente ensaio enaltece a riqueza de análises dialógicas entre a teoria e a prática política, descortinando continuidades e rupturas que perpassam a relação entre as duas.

Daniela Resende Archanjo (danielaarchanjo@ufpr.br) é Doutora em História pela Universidade Federal do Paraná (UFPR).

\section{REFERÊNCIAS BIBLIOGRÁFICAS}

AGRIPINO, J. 1952. Declaração de voto. Diários da Câmara dos Deputados, Brasília, 12.jun. Disponível em: http://imagem.camara.gov.br/ diarios.asp. Acesso em: 29.dez.2010.

ANNIBELLI, A. 1975. Declaração de voto. Diários do Congresso Nacional, Brasília, 9.maio. Disponível em: http://imagem.camara.gov.br/ diarios.asp. Acesso em: 29.dez.2010.

ARAUJO, C. 2006. Representação, retrato e drama. Lua Nova, São Paulo, n. 67, p. 229-260. Disponível em: http://www.scielo.br/pdf/ln/ n67/a08n67.pdf. Acesso em: 29.dez.2010.

ARBAGE, J. 1976. Declaração de voto. Diários do Congresso Nacional, Brasília, 10.mar. Disponível em: http://imagem.camara.gov.br/ diarios.asp. Acesso em: 29.dez.2010.

ARCHANJO, D. R. 2006. O adultério no limiar do século XXI. Um estudo das suas representações sociais. Curitiba: Aos Quatro Ventos.

2008. Um debate sem embate: a discussão sobre o divórcio no Congresso Nacional (Bra- sil, 1951-1977). Curitiba. Tese (Doutorado em História). Universidade Federal do Paraná.

BURKE, E. 1774. Discurso aos eleitores de Bristol. Disponível em: http://www.senado. gov.br/senadores/senador/geraldomesquita/ Textos/cursos/UniV_Filosofos\%20.pdf. Acesso em: 29.dez.2010.

CÂMARA, A. 1956. Declaração de voto. Diários da Câmara dos Deputados, Brasília, 29.maio. Disponível em: http://imagem.camara.gov.br/ diarios.asp. Acesso em: 29.dez.2010.

. 1961. Discurso. Diários da Câmara dos Deputados, Brasília, 20.nov. Disponível em: http://imagem.camara.gov.br/diarios.asp. Acesso em: 29.dez.2010.

1962. Discurso. Diários da Câmara dos Deputados, Brasília, 27.fev. Disponível em: http://imagem.camara.gov.br/diarios.asp. Acesso em: 29.dez.2010.

CARNEIRO, N. 1959. Discurso. Diários da Câmara dos Deputados, Brasília, 29.nov. Dis- 
ponível em: http://imagem.camara.gov.br/ diarios.asp. Acesso em: 29.dez.2010.

1962. Discurso. Diários da Câmara dos Deputados, Brasília, 25.abr. Disponível em: http://imagem.camara.gov.br/diarios.asp. Acesso em: 29.dez.2010.

1971. Declaração de voto. Diários do Congresso Nacional, Brasília, 28.abr. Disponível em: http://imagem.camara.gov.br/ diarios.asp. Acesso em: 29.dez.2010.

1975. Discursos do expediente. Diários do Congresso Nacional, Brasília, 19.mar. Disponível em: http://imagem.camara.gov.br/ diarios.asp. Acesso em: 29.dez.2010.

CARVALHO, A. 1977. Declaração de voto. Diários do Congresso Nacional, Brasília, 16.jun. Disponível em: http://imagem.camara.gov.br/ diarios.asp. Acesso em: 29.dez.2010.

COTTA, M. 1992. Representação política. In: BOBBIO, N.; MATTEUCCI, N. \& PASQUINO, G. (orgs.). Dicionário de politica. $4^{\mathrm{a}}$ ed. V. 2. Brasília: UNB

COUTINHO, F. 1971. Declaração de voto. Diários da Câmara dos Deputados, Brasília, 6.nov. Disponível em: http://imagem.camara.gov.br/ diarios.asp. Acesso em: 29.dez.2010.

FARACO, D. 1952. Discurso. Diários da Câmara dos Deputados, Brasília, 19.fev. Disponível em: http://imagem.camara.gov.br/ diarios.asp. Acesso em: 29.dez.2010.

1962. Discurso. Diários da Câmara dos Deputados, Brasília, 11.abr. Disponível em: http://imagem.camara.gov.br/diarios.asp. Acesso em: 29.dez.2010.

FERRARI, F. 1952. Discurso. Diários da Câmara dos Deputados, Brasília, 12.jun. Disponível em: http://imagem.camara.gov.br/ diarios.asp. Acesso em: 29.dez.2010.

FERREIRA, B. 1975. Discurso. Diários do Senado Federal, Brasília, 20.set.

1977. Declaração de voto. Diários do Congresso Nacional, Brasília, 23.jun. Disponível em: http://imagem.camara.gov.br/ diarios.asp. Acesso em: 29.dez.2010.

FREIRE, G. 1977. Discursos do expediente. Diários do Congresso Nacional, Brasília, 15.jun.
Disponível em: http://imagem.camara.gov.br/ diarios.asp. Acesso em: 29.dez.2010.

FURTADO, C. 1975. Discurso. Diários do Congresso Nacional, Brasília, 9.maio. Disponível em: http://imagem.camara.gov.br/diarios.asp. Acesso em: 29.dez.2010.

GARCIA, L. 1952. Discurso. Diários da Câmara dos Deputados, Brasília, 26.jul. Disponível em: http://imagem.camara.gov.br/diarios.asp. Acesso em: 29.dez.2010.

LAMOUNIER, B. \& MENEGUELLO, R. 1986. Partidos politicos e consolidação democráti$c a$ : o caso brasileiro. São Paulo: Brasiliense.

LIMA, M. F. Discurso. Diários da Câmara dos Deputados, Brasília, 7.maio. Disponível em: http://imagem.camara.gov.br/diarios.asp. Acesso em: 29.dez.2010.

MANIN, B.; PRZEWORSKI, A. \& STOKES, S. C. 2006. Eleições e representação. Lua Nova, São Paulo, n. 67, p. 105-136. Disponível em: http://www.scielo.br/pdf/ln/n67/a05n67.pdf. Acesso em: 29.dez.2010.

MEZZAROBA, O. 2004. Introdução ao Direito Partidário brasileiro. Rio de Janeiro: Lúmen Júris.

MIGUEL, L. F. 2005. Impasses $d a$ accountability: dilemas e alternativas da representação política. Revista de Sociologia Política, Curitiba, n. 25 , p. $25-38$, nov. Disponível em: http:// www.scielo.br/pdf/rsocp/n25/31109.pdf. Acesso em: 29.dez.2010.

MIKILITA, E. 1962. Discurso. Diários da Câmara dos Deputados, Brasília, 24.fev. Disponível em: http://imagem.camara.gov.br/ diarios.asp. Acesso em: 29.dez.2010.

NOBRE, P. 1966. Discurso. Diários da Câmara dos Deputados, Brasília, 28.abr. Disponível em: http://imagem.camara.gov.br/diarios.asp. Acesso em: 29.dez.2010

1975. Discurso. Diários da Câmara dos Deputados, Brasília, 24.abr. Disponível em: http://imagem.camara.gov.br/diarios.asp. Acesso em: 29.dez.2010.

PITKIN, H. F. 2006. Representação: palavras, instituições e idéias. Lua Nova, São Paulo, n. 67, p. 15-47. Disponível em: http:// 
www.scielo.br/pdf/ln/n67/a03n67.pdf. Acesso em: 29.dez.2010.

RAMOS, B. 1975. Discurso. Diários da Câmara dos Deputados, Brasília, 13.mar. Disponível em: http://imagem.camara.gov.br/diarios.asp. Acesso em: 29.dez.2010.

RIBEIRO, N. Discurso. Diários da Câmara dos Deputados, Brasília, 11.mar. Disponível em: http://imagem.camara.gov.br/diarios.asp. Acesso em: 29.dez.2010.

RODRIGUES, L. 1975. Discurso. Diários da Câmara dos Deputados, Brasília, 15.maio. Disponível em: http://imagem.camara.gov.br/ diarios.asp. Acesso em: 29.dez.2010.

SANTOS, R. 1977. Declaração de voto. Diários do Congresso Nacional, Brasília, 15.jun. Disponível em: http://imagem.camara.gov.br/ diarios.asp. Acesso em: 29.dez.2010.

SCHMITT, R. 2000. Partidos políticos no Brasil (1945-2000). Rio de Janeiro: J. Zahar.

SOUSA, J. P. G. 1971. Da representação política. São Paulo: Saraiva.

URBINATI, N. 2006. O que torna a representação democrática? Lua Nova, São Paulo, n. 67, p. 191-228. Disponível em: http:// www.scielo.br/pdf/ln/n67/a07n67.pdf. Acesso em: 31.dez.2010.

VALOIS, F. 1952. Discurso. Diários da Câmara dos Deputados, Brasília, 12.jun. Disponível em: http://imagem.camara.gov.br/diarios.asp. Acesso em: 29.dez.2010.

VAZ, B. 1962. Discurso. Diários da Câmara dos Deputados, Brasília, 14.fev. Disponível em: http://imagem.camara.gov.br/diarios.asp. Acesso em: 29.dez.2010.

VERGAL, C.1962. Discurso. Diários da Câmara dos Deputados, Brasília, 14.abr. Disponível em: http://imagem.camara.gov.br/diarios.asp. Acesso em: 29.dez.2010.

YOUNG, I. M. 2006. Representação política, identidade e minorias. Lua Nova, São Paulo, n. 67, p. 139-190. Disponível em: http:// www.scielo.br/pdf/ln/n67/a06n67.pdf. Acesso em; 29.dez.2010.

ZAVAGLIA, J. Discurso. Diários da Câmara dos Deputados, Brasília, 29.abr. Disponível em: http://imagem.camara.gov.br/diarios.asp. Acesso em: 29.dez.2010.

\section{OUTRA FONTE}

TRIBUNAL SUPERIOR ELEITORAL. 1960. Eleições federais, estaduais e municipais realizadas no Brasil em 1952, 1954 e 1955, e em confronto com anteriores. In: TRIBUNAL SUPERIOR ELEITORAL. Dados Estatísticos. 3. V. Rio de Janeiro: Tribunal Superior Eleitoral. 


\section{POLITICAL REPRESENTATION: A DIALOG BETWEEN PRACTICE AND THEORY}

\section{Daniela Resende Archanjo}

The present essay discusses the issue of political representation through a dialog between political theory and practice. Beginning from the characterization of three forms of representation noted in the bibliography (representation as delegation, as trust and as sociological representativity) the article seeks to reveal, through the speech of house representatives and senators who participated in the debate around the institution of divorce during the 1950s, 1960s and 1970s, how different possibilities regarding the concept of political representation were understood and mobilized in political debate within the Brazilian Congress. The context surrounding the House of Representatives and the Federal Senate, political scenario par excellence, is multi-faceted, while parliamentary practice is constituted through the (unconscious) mixture of theoretical models, in which the need to express the importance of maintaining ties to the voter always prevails. We must not forget that politicians' discourse is, above and beyond all else, the product of the contexts to which they belong, forged by the meanings that members of parliament attribute to their function as political representatives.

KEYWORDS: Political Representation; Political Theory; Political Practice; Divorce. 


\section{Daniela Resende Archanjo}

Cet article discute la question de la représentation politique à partir du dialogue entre la théorie et la pratique de la politique. En partant de la caractérisation des trois formes de représentation indiquées par la bibliographie (représentation tant que délégation, tant que confiance et tant que représentativité sociologique), l'article cherche à révéler, à partir des discours des députés et sénateurs qui ont participé du débat autour de l'institution du divorce au Brésil pendant les décennies de 1950, 1960 et 1970, comment les différentes possibilités du concept de représentation politique ont été comprises et mobilisées dans le débat politique du Congrès National. Le contexte où sont inscrits le Sénat Fédéral et la Chambre de Députés, scénario de la politique par excellence, a des multiples facettes, pendant que la pratique parlementaire se constitue dans le mélange (inconscient) des modèles théoriques, où la nécessité d'exprimer l'importance de l'entretien du lien avec l'électeur prévaut toujours. Il faut ne pas perdre de vue que les discours des politiques sont, avant tout, des produits du contexte où ils sont inscrits, masqués par le significat attribué par les parlementaires à leur fonction de représentants politiques.

MOTS-CLES: représentation politique; Théorie Politique; pratique politique; divorce. 